\title{
PERSEPSI MAHASISWA TERHADAP GAGASAN LEGALISASI GANJA DI INDONESIA
}

\author{
Hanri Aldino \\ Dosen Fakultas Hukum, Universitas Samudra \\ Jl. Meurandeh Gp. Meurandeh Kec. Langsa Lama Kota Langsa, Aceh 24416 \\ thealdino@yahoo.co.id
}

\begin{abstract}
As of today, Indonesian law still prohibit the process of production, distribution, and consumption of marijuana according to Indonesian law about narcotics No. 35 year 2009. However, there is a quite interesting phenomenon signed by a public act supporting marijuana legalization in Indonesia. This research is conducted to explain society's attitude about the idea of legalizing marijuana in Indonesia and the influencing factors of the attitude. The subject of this research is limited to the university student society. This post-positivist research is using non-parametric statistic method. And the result of this research shows that university students in Indonesia are taking neutral side in the idea of legalizing marijuana. They agree in the use of marijuana for industrial and medical purposes, but disagree in the recreational purpose of marijuana. This attitude is influenced by four factors: gender, self experience, significant others, and media.

Keywords: Perception, legalization of cannabis
\end{abstract}

Abstrak, Ganja merupakan tamanan yang ilegal di Indonesia saat ini. Indonesia bahkan mengeluarkan Undang-Undang Narkotika No. 35 Tahun 2009 tentang larangan proses produksi, distribusi sampai tahap konsumsi dari tanaman ganja. Namun terdapat fenomena yang sangat menarik ditandai dengan kehadiran sebuah gerakan yang mendukung legalisasi ganja di Indonesia. Penelitian ini dilakukan untuk menjelaskan sikap seseorang terhadap gagasan legalisasi ganja di Indonesia serta faktor-faktor apa saja yang mempengaruhi pembentukan sikap tersebut. Lingkup penelitian dibatasi pada mahasiswa, menggunakan paradigma post-positivis dengan uji statistik non parametrik. Hasil penelitian menunjukkan bahwa mahasiswa ternyata bersikap netral terhadap gagasan legalisasi ganja di Indonesia, dengan penjelasan setuju kepada pemanfaatan ganja untuk industri dan medis, namun tidak setuju untuk rekreasional. Dan sikap tersebut dipengaruhi oleh empat faktor, yakni gender, self experience, significant others, dan media.

Kata Kunci : Persepsi, legalisasi, Ganja

\section{Pendahuluan}

Ganja merupakan tamanan yang ilegal di Indonesia saat ini. Indonesia bahkan mengeluarkan undang-undang tentang larangan proses produksi, distribusi sampai tahap konsumsi dari tanaman ganja. Berdasarkan Lampiran I butir 8 Undang-Undang No. 35 Tahun 2009 tentang Narkotika, tanaman ganja termasuk dalam narkotika golongan I. Dijelaskan dalam Pasal 7 UU 35/2009, narkotika hanya dapat digunakan untuk kepentingan pelayanan kesehatan dan/atau pengembangan ilmu pengetahuan dan 
teknologi. Dalam Penjelasan Pasal 7 UU 35/2009, diterangkan bahwa yang dimaksud dengan "pelayanan kesehatan" adalah termasuk pelayanan rehabilitasi medis. Yang dimaksud dengan "pengembangan ilmu pengetahuan dan teknologi" adalah penggunaan narkotika terutama untuk kepentingan pengobatan dan rehabilitasi, termasuk untuk kepentingan pendidikan, pelatihan, penelitian dan pengembangan, serta keterampilan yang dilaksanakan oleh instansi pemerintah yang tugas dan fungsinya melakukan pengawasan, penyelidikan, penyidikan, dan pemberantasan peredaran gelap narkotika. Kepentingan pendidikan, pelatihan dan keterampilan adalah termasuk untuk kepentingan melatih anjing pelacak narkotika dari pihak Kepolisian Negara Republik Indonesia, Bea dan Cukai serta Badan Narkotika Nasional serta instansi lainnya. ${ }^{1}$

Hal ini membuat ganja menjadi tanaman yang kontroversial karena sejarahnya yang lekat dengan budaya di Indonesia. Di Aceh, tanaman ini berfungsi sebagai penyedap masakan untuk berbagai jenis masakan, seperti gulai kambing, dodol Aceh, mie Aceh, kopi Aceh dan sebagainya untuk menambah cita rasa makanan. ${ }^{2}$ Menurut sejarah, tanaman ganja masuk ke wilayah Aceh sejak abad ke-19 dari India. Ketika itu, Belanda membuka perkebunan kopi di Dataran Tinggi Gayo dan menggunakan ganja sebagai obat alami untuk menghindari serangan hama pohon kopi atau ulat pada tanaman tembakau. Setelah bertahun-tahun dan tumbuh menyebar hampir di seluruh Aceh, ganja mulai dikonsumsi, terutama dijadikan 'rokok enak,' yang lambat laun menjadi tradisi di Aceh hingga daerah lain di Sumatera sebagai tambahan rempah dalam resep masakan. Tradisi ini memang sulit dihilangkan.

Mulai dari era 60-an hingga era 80 -an, ganja memang sangat populer di dunia. Munculnya era dimana ganja menjadi menu utama sehari-hari bagi komunitas yang menyatakan dirinya sebagai Flower Generation dalam bentuk lintingan-lintingan dan dikonsumsi seperti cara merokok. Flower Generation, adalah anak-anak muda berumur di bawah 30 tahun yang hidup di era akhir 1960-an. Di Indonesia, ganja "naik daun" pada tahun 1970an, bersamaan dengan gelombang Flower Generation tersebut di Amerika, yang orang-orangnya populer dengan sebutan Hippies. Di Jogyakarta, salah satu daerah di Indonesia, ganja banyak dibawa turis-turis asing di Malioboro, dikonsumsi sebagai rokok yang disebut "gelek". Ganja semakin populer disebut "cimeng" dan dipakai sebagai zat pengganti bila heroin tak bisa didapat. ${ }^{3}$ Ini menimbulkan dampak yang berbahaya karena diaggap dapat merusak generasi muda. Sehingga di era ini peredaran ganja sangat dilarang.

Semakin banyak pula argumen yang juga memperkuat bahwa ganja memiliki unsur zat adiktif yang membahayakan penggunanya. Dadang Hawari mengatakan bahwa perubahan perilaku tersebut meliputi palpitasi (jantung yang berdebar-debar), halusinasi

\footnotetext{
${ }^{1}$ Tobing, Letezia. Hukum Menanam Cannabis (Ganja), http://www.hukumonline.com/klinik/detail/lt522150607489f/hukum-menanam-cannabis-(ganja), diakses pada pada tanggal 19 Oktober 2017.

${ }^{2}$ Gobel, Fatmah Afrianty, Ganja Aceh Untuk Medis, Halalkah?., http://www.atjehcyber.net/2011/11/ganja-aceh-demi-dunia-medis.html, diakses pada tanggal 23 Oktober 2017.

${ }^{3}$ Wicaksana, Inu, Jaman Dulu 'Gelek', Sekarang 'Cimeng', Itulah Ganja Pengganti HeroinI, http://kesehatan.kompasiana.com/kejiwaan/ 2011/05/27/jaman-dulu-gelek-sekarang-cimengitulah-ganja-pengganti-heroin-368354.html, diakses pada tanggal 24 oktober 2017.
} 
dan delusi, perasaan waktu berlalu dengan lambat, dan adaptis (acuh tak acuh, masa bodoh, tidak perduli terhadap tugas dan fungsinya sebagai mahluk sosial). Dalam praktek sehari-hari ternyata penyalahgunaan ganja dapat menjadi pencetus bagi terjadinya gangguan jiwa (psikosis). Frekuensi yang tinggi dalam mengonsumsi ganja secara rekreasional juga terbukti berpotensi untuk depresi dan kecemasan yang berlebihan. ${ }^{4}$

Di luar negeri, ganja dibedakan menjadi dua bagian, yaitu ganja untuk kepentingan industri maupun medis yaitu ganja jenis Hemp, dan ganja terlarang sering disebut Cannabis. Hemp mengandung THC di bawah $0,3 \%$, sedangkan cannabis bisa mencapai $6 \%$ sampai $20 \%$. Sementara di Indonesia tidak mengenal perbedaan ini, seperti yang tercantum dalam Undang-Undang No. 35 Tahun 2009 tentang Narkotika disebutkan bahwa ganja termasuk sebagai narkotika golongan $1 .^{5}$

Penyalahgunaan pemakaian ganja sering dilakukan kalangan muda, biasanya mereka menggunakan untuk meningkatkan rasa percaya diri. Data jumlah penyalahguna narkoba per provinsi menurut jenis narkoba tahun 2011, yang diterbitkan oleh BNN (Badan Nasional Narkotika) dan Puslitkes UI pada bulan Maret 2012, menyebutkan bahwa jumlah penyalahguna ganja adalah 2.816 .429 orang. Dari data tersebut dapat dilihat dengan sangat jelas bahwa ganja menduduki peringkat pertama, $65.9 \%$ dari total penyalahguna narkoba di Indonesia. ${ }^{6}$

Hal ini mengalami peningkatan yang cukup signifikan berdasarkan data terbaru dari BNN mengenai jumlah pengguna Narkoba di Indonesia hingga April 2013 yang telah mencapai 4 juta orang. Dari total pengguna Narkoba di Indonesia sebagian besar anakanak usia remaja. Hasil survei Badan Narkotika Nasional (BNN) lainnya juga menunjukkan, prevalensi penyalahgunaan narkoba di lingkungan pelajar mencapai 4,7 persen dari jumlah pelajar dan mahasiswa atau sekitar 921.695 orang.

Sedangkan berdasarkan data Perhimpunan Ahli Penyakit Dalam Indonesia (PAPDI) cabang DKI Jaya, mayoritas pengguna narkotika berumur 20-25 tahun dan dengan proporsi $90 \%$ pria. Remaja di kota-kota besar seperti Medan, Jakarta, Bandung, Surabaya, Denpasar menjadi daerah tujuan pasar narkotika Internasional. ${ }^{7}$ Menurut lensaindonesia.com, saat ini Jawa Barat menempati urutan terbesar kedua setelah Aceh, dalam peredaran narkotika jenis ganja di Indonesia dan besarnya jumlah peredaran ini berhubungan dengan banyaknya angka pengguna ganja. Statistik besarnya peredaran ganja di Jabar itu diketahui berdasarkan hasil penelitian oleh Universitas Indonesia.

Berdasarkan perjalanan kontroversial ganja yang menjadi ilegal dan diatur keras dalam hukum Indonesia saat ini, padahal sangat lekat dengan budaya sebagian daerah Indonesia beserta kegunaan lainnya yang memberi manfaat, lahirlah suatu fenomena yang sangat menarik. Hal ini ditandai dengan kehadiran sebuah gerakan yang mendukung legalisasi ganja. Gagasan ini menjadi suatu gerakan yang disasarkan kepada masyarakat

\footnotetext{
${ }^{4}$ Patton, George C dkk., Cannabis Use and Mental Health in Young People: (Cohort Study., 2002). hlm. 13

${ }^{5}$ Hart, Carl L. At all. Drugs, Society and Human Behavior. (New York: McGraw-Hill., 2009), hlm. 33

${ }^{6}$ Sharley, Delvi., Budaya Ganja di Aceh., http://www.legalisasiganja.com/budaya-ganja-di-aceh/, diakses pada tanggal 24 oktober 2017.

${ }^{7}$ Ibid.
} 
untuk setuju dan percaya bahwa ganja seharusnya menjadi tanaman yang legal, khususnya di Indonesia. Padahal jelas secara hukum ganja sangat dilarang dan secara medis juga mendukung bahwa ganja merupakan tanaman yang memiliki dampak buruk bagi seseorang apabila dikonsumsi tanpa ketentuan medis yang diperbolehkan.

Salah satu penggagas legalisasi ganja di Indonesia adalah Organisasi Lingkar Ganja Nusantara. Organisasi ini berawal dari sebuah grup "Dukung Legalisasi Ganja" yang dibuat di situs jejaring sosial Facebook. Dengan tujuan untuk membuat ganja menjadi legal di Indonesia, para pengurusnya aktif menyosialisasikan manfaat tanaman ganja kepada semua elemen masyarakat. ${ }^{8}$ Atas dasar ini, "Lingkar Ganja Nusantara" memiliki aktivitas sebagai organisasi yang bertugas menyebarkan informasi mengenai tanaman ganja, hubungan serta manfaatnya bagi manusia kepada seluas-luasnya masyarakat.

Misalnya, dalam buku "Hikayat Pohon Ganja" mereka mengangkat argument Francis Young, mantan Kepala Administrasi Hakim Hukum di Drug Enforcement Administration (DEA) Amerika sekaligus seorang $\mathrm{PhD}$ dengan keterlibatan post-doktoral yang signifikan dalam masalah medis yang berhubungan dengan mariyuana atau ganja, dalam tulisannya yang berjudul "Opinion and Recommended Ruling, Finding of fact, Conclutions of Law and Decision of Administrative Law Judge" (1988). Ia menyatakan bahwa ganja, dengan konsumsi di bawah pengawasan medis, jauh lebih aman dari kebanyakan makanan yang kita konsumsi. Ganja bahkan disebut sebagai tanaman obat yang memiliki fungsi medis paling banyak dibanding tanaman obat. ${ }^{9}$ Hingga tahun 2008, 12 negara, meliputi Belanda, Jerman, Argentina, Siprus, Ekuador, Meksiko, Peru, Swiss, Spanyol, Belgia, Republik Ceko, Brazil, Chili, Uruguay, Paraguay, Kolombia Australia, dan Amerika Serikat, telah memiliki bentuk legalisasi ganja bagi pasien yang memang benar-benar memerlukan sesuai dengan resep dokter dan dapat dipertanggungjawabkan secara medis. ${ }^{10}$

Pasien penderita HIV/AIDS mengonsumsi ganja untuk mengobati berbagai gejala seperti kecemasan, kehilangan nafsu makan, dan mual-mual. (Belle-Isle, 2007). Pernyataan tersebut diperjelas dengan data survei oleh S. Sidney pada tahun 2001 yang menunjukkan bahwa penggunaan ganja untuk tujuan medis relatif umum digunakan pada pasien HIV-AIDS positif. Dari 442 responden, pasien HIV-AIDS positif, alasan yang paling umum untuk menggunakan ganja adalah untuk merasa lebih baik secara mental atau mengurangi stres $(79 \%)$, meningkatkan nafsu makan atau berat badan $(67 \%)$ dan mengurangi mual (66\%). Survey ini dilakukan pada peserta dari klinik HIV di San Francisco, Oakland, dan medical centers of the Kaiser Permanente Medical Care Program (KPMCP) di California.

Organisasi Lingkar Ganja Nusantara juga berpendapat bahwa ganja memiliki potensi tinggi untuk dimanfaatkan sebagai sumber serat tekstil, lebih baik dari tanaman kapas, atau bubur kertas. Dalam artikel berjudul "World's Oldest Fabric in Its Newest" di

\footnotetext{
${ }^{8}$ Narayana, Dhira dkk. Hikayat Pohon Ganja. (Jakarta: PT Gramedia Pustaka Utama, 2011), hlm. 41

${ }^{9}$ Ibid., hlm. 42-43

${ }^{10}$ Hart, Carl L. At all. Drugs, Society and Human Behavior. (New York: McGraw-Hill. 2009), hlm. 33
} 
New York Times, Juni 1995, Calvin Klein mengeluarkan pernyataan bahwa ganja akan menjadi serat pilihan bagi perabot rumah dan industri pakaian. ${ }^{11}$ Pernyataan tersebut diamini seiring dengan perubahan persepsi terhadap tanaman ganja di negara Amerika Serikat yang sekarang menjadi salah satu icon modis. Artikel yang berjudul "Armani, Calvin Klein, \& Whole Foods like hemp" yang ditulis oleh Nicolas Eyle pada tahun 2010, desainer Stella McCartney, Giorgio Armani dan Calvin Klein telah memasukkan tekstil dari serat ganja ke dalam kain bahan mereka.

Efek yang dimunculkan dari penyebaran gagasan legalisasi ganja di Indonesia adalah terbentuknya sikap (attitude) pada masyarakat dalam menanggapinya. Sikap (attitude) tidaklah terbentuk dengan sendirinya karena pembentukan sikap senantiasa akan berlangsung dalam interaksi manusia berkenaan dengan obyek tertentu. ${ }^{12}$ Sikap (attitude) terdiri dari 3 dimensi yang secara bersama-sama membentuk penilaian terhadap objek sikap, yakni kognitif, afektif dan konatif/behavioural. Dalam hal ini objek sikap tersebut adalah pesan-pesan atau gagasasan mengenai legalisasi ganja di Indonesia. Sikap masyarakat terhadap gagasan legalisasi ganja ini menjadi penting diketahui karena akan mempengaruhi pembentukan preferensi serta penerimaan mereka terhadap gagasan yang ditawarkan secara persuasif. ${ }^{13}$

Sikap terhadap obyek sikap dapat dipengaruhi oleh beberapa faktor, yakni self experience, culture, significant others, media, dan gender. Self experience dan significant others sangat berpengaruh terhadap sikap (attitude). Mereka menemukan bahwa terdapat empat kelompok posisi sikap (attitude) terhadap penggunaan narkoba. Kelompok pertama bersikap anti-narkoba dimiliki oleh para pemuda yang tidak menggunakan obat-obatan terlarang dan tidak memiliki teman pengguna narkoba; kelompok kedua bersikap ambivalen, dipegang oleh non-pengguna namun memiliki teman pengguna narkoba; kelompok ketiga bersikap sementara, dipegang oleh pengguna ganja dengan lingkungan pertemanan yang belum menjadi pengguna, namun berpotensi untuk masuk dalam posisi pro-obat; sedang kelompok keempat bersikap pro-obat, dipegang oleh pengguna narkoba dan lingkungan pertemanan yang juga pengguna dengan orientasi kesenangan yang tinggi.

Selain itu, sikap juga ternyata dipengaruhi oleh budaya atau kebiasaan seseorang. Variabel kebudayaan mempunyai hubungan positif dan signifikan terhadap sikap (attitude). Hal ini dijelaskan dengan hasil penelitiannya yang menyatakan bahwa terdapat perbedaan antara sikap suku francophones (orang-orang berasal dari Prancis yang sudah lama tinggal di Kanada) dengan ontario anglophones (suku asli yang ada di Kanada). Orang Prancis dinilai memiliki sikap yang lebih peduli terhadap masalah lingkungan global dibandingkan ontario.

Berangkat dari latar belakang diatas, penelitian ini dilakukan untuk menjelaskan sikap (attitude) seseorang terhadap gagasan legalisasi ganja di Indonesia serta melihat faktor-faktor apa saja yang mempengaruhi pembentukan sikap (attitude) tersebut. Hal ini menjadi penting untuk diketahui karena sikap (attitude) tersebut pada akhirnya akan

\footnotetext{
${ }^{11}$ Narayana, Dhira dkk. 2011. Hikayat Pohon Ganja ... hlm. 51

12 Oskamp, Stuart dan Schultz, P. Wesley. Attitudes and Opinions. (London: Lawrence Erlbaum, 2005), hlm. 12

${ }^{13}$ Ibid.
} 
mempengaruhi pembentukan preferensi serta penerimaan mereka terhadap gagasan legalisasi ganja yang merupakan isu yang sangat penting dibahas di Indonesia. Lingkup penelitian dibatasi pada mahasiswa karena dianggap telah mampu membuat keputusan sendiri dan peka terhadap fenomena serta isu sosial politik masyarakat yang terjadi.

Hal yang menjadi pokok permasalahan dalam penelitian ini penulis membahas mengenai persepsi mahasiswa terhadap legalisasi ganja di indonesia?.

\section{Metode Penelitian}

Penelitian ini menggunakan paradigma post-positivisme dengan pendekatan kuantitatif. Berdasarkan tujuannya, jenis penelitian ini termasuk dalam penelitian eksplanatif dimana peneliti berusaha menjelaskan hubungan antara variabel satu dan yang lain serta membuktikan hubungan atau pengaruh antar variabel tersebut. ${ }^{14}$ Maka dari itu, penelitian ini berusaha menjelaskan faktor apa saja yang berpengaruh secara signifikan serta menganalisa perbedaan-perbedaan sikap yang diakibatkan karenanya. Berdasarkan manfaatnya, maka penelitian ini tergolong ke dalam penelitian murni (basic research) dan dilakukan pada satu waktu tertentu serta tidak akan dilakukan penelitian lain di waktu yang berbeda untuk diperbandingkan.

Metode pengumpulan data utama yang dilakukan peneliti adalah melalui survei dengan cara menyebarkan kuesioner. Metode pengukuran yang digunakan yakni skala Likert 1-5. Kuesioner yang digunakan diuji terlebih dahulu reabilitasnya menggunakan pre-test terhadap 30 responden. Sedangkan teknik analisis data yang digunakan meliputi analisis deskriptif yakni dengan cara pengumpulan data dan penyajian data sehingga mudah dipahami. deskriptif hanya berhubungan dengan hal menguraikan atau memberikan keterangan-keterangan mengenai suatu data atau keadaan. Dengan kata analisis deskriptif berfungsi menerangkan keadaan, gejala, atau persoalan.

\section{Pembahasan}

\section{A. Tinjauan Teoritis}

1. Konsep Sikap (Attitude)

Merupakan sebuah konsep multidimensional yang dikonstruksikan pada diri masing-masing individu sebagai timbal balik dari suatu perilaku komunikasi. La Pierre dalam Azwar, mendefinisikan sikap (attitude) sebagai suatu pola perilaku, tendensi atau kesiapan antisipatif, predisposisi untuk menyesuaikan diri dalam situasi sosial, atau secara sederhana. ${ }^{15}$ Sikap adalah respon terhadap stimuli sosial yang telah terkondisikan. Jalaluddin Rakhmat dalam bukunya "Psikologi Komunikasi" menyatakan bahwa sikap (attitude) merupakan kecenderungan bertindak, berpersepsi, berpikir, dan merasa dalam menghadapi objek, ide, situasi, atau nilai.

Fungsi Sikap (Attitude) secara umum merupakan dasar motivasi yang membentuk dan memperkuat sikap positif atau negatif pada suatu objek. Menurut Katz dalam buku Wawan dan Dewi, fungsi-fungsi tersebut meliputi Utilitarium Function (seseorang

${ }^{14}$ Zulganef., Metode Penelitian Sosial \& Bisnis. (Yogyakarta: Graha Ilmu., 2008). hlm. 18

15 Azwar, Saiffudin., Sikap Manusia Teori dan Pengukurannya, (Yogyakarta: Pustaka Pelajar, 2003), hlm. 44 
menyukai suatu gagasan dikarenakan fungsi atau manfaat yang akan didapat pada dirinya), The Ego Defensife Function (keberadaan sikap akan melindungi seseorang dari ancaman eksternal maupun perasaan dari dalam dirinya), Value-Expressive Function (seseorang membentuk sikap terhadap suatu gagasan bukan karena manfaatnya, melainkan apa yang dikatakan gagasan tersebut tentang diri mereka), dan Knowledge Function (apabila seseorang mempunyai sikap tertentu terhadap suatu obyek, menunjukkan tentang pengetahuan orang terhadap obyek sikap yang bersangkutan). ${ }^{16}$

Sikap (attitude) merupakan konsep yang ada pada tataran pikiran dan perasaan manusia. Konsep ini juga sangat relatif namun tetap bisa diukur dan dijelaskan dengan beberapa komponen dimensi. Sikap (attitude) dipandang sebagai kombinasi reaksi kognitif, afektif dan perilaku terhadap suatu objek. ${ }^{17}$ Ketiga komponen tersebut secara bersama mengorganisasikan sikap individu. Uraian tersebut dikenal dengan nama skema triadik, atau pendekatan tricomponent yang diuraikan secara lebih rinci pada penjelasan berikut: Kognitif, terdiri dari pikiran-pikiran dan keyakinan-keyakinan seseorang terhadap objek sikap, misalnya wujud, gagasan atau konsep. Afektif, berkaitan dengan perasaan yang menyangkut reaksi emosi seseorang terhadap objek sikap. Konatif/behavioural, terdiri dari tindakan atau kecenderungan orang untuk berperilaku yang nampak terhadap objek sikap.

Masing-masing aspek tersebut memang merupakan komponen yang kontrak teoritiknya berbeda satu sama lain. Sikap merupakan suatu konsep multidimensional yang terdiri dari kognitif, afektif dan konatif seperti yang telah diuraikan di atas. Sekalipun kesemua komponen berada pada suatu kontinum evaluatif akan tetapi pernyataan masingmasing dapat berbeda. ${ }^{18}$

\section{Gagasan Legalisasi Ganja di Indonesia}

Obyek sikap dalam penelitian ini adalah gagasan legalisasi ganja di Indonesia. Secara harfiah menurut Kamus Besar Bahasa Indonesia (KBBI), ide/gagasan adalah rancangan yang tersusun di pikiran. Menurut Schramm, gagasan merupakan pesan yang disampaikan atau dinyatakan jika terjadi komunikasi terhadap dua pihak untuk memperoleh pandangan mengenai objek tertentu. ${ }^{19}$ Dalam studi komunikasi, ide/gagasan inilah yang menjadi pesan dalam perjalanan proses komunikasi berlangsung, tentu saja baik melalui lisan, tulisan, verbal, maupun non-verbal. Legalisasi berasal dari kata serapan to legalize/legalization, yang memiliki bermacam makna tergantung konteks yang hendak dibicarakan. Namun pada intinya legalisasi adalah proses membuat sesuatu menjadi legal/sah/resmi. Proses itu sendiri juga bermacam-macam mulai dari pembuatan hukum positif (UU, Perpres, Perda dll), ratifikasi, pembuatan akta-akta hukum, hingga keputusan hakim/pengadilan.

Berdasarkan pengertian diatas maka legalisasi ganja dapat diartikan sebagai upaya membuat tanaman ganja yang saat ini illegal dan diatur dalam Undang-Undang

\footnotetext{
${ }^{16}$ Wawan. A dan M. Dewi. Teori dan Pengukuran Pengetahuan, Sikap, Dan Perilaku Manusia Dilengkapi contoh Kuesioner. Cetakan Pertama. (Yogyakarta: Nuha Medika., 2010), hlm. 23

${ }^{17}$ Azwar, Saiffudin., Sikap Manusia Teori dan Pengukurannya ... hlm. 49

${ }^{18}$ Ibid.

${ }^{19}$ Ibid.
} 
Narkotika, menjadi legal penggunaannya. Legal disini adalah resmi dan sah oleh negara, namun tidak terlepas pula dari peraturan perudang-undangan.

Gagasan legalisasi ganja di Indonesia banyak digaungkan oleh organisasi Lingkar Ganja Nusantara. Legalisasi ganja yang dimaksud adalah adanya pembentukan UU Pengelolaan Ganja Republik Indonesia yang seirama dengan ajaran Pancasila dengan argumen-argumen yang dibangun atas dasar pengetahuan mengenai tiga manfaat utama pohon ganja, yakni dalam bidang industri, medis dan rekreasional. ${ }^{20}$

Faktor yang Mempengaruhi Sikap (Attitude)

Dari berbagai referensi yang ditelusuri oleh peneliti, terdapat beberapa faktor yang dapat mempengaruhi pembentukan sikap (attitude), antara lain:

- Self Experience (Pengalaman Pribadi)

Pembentukan sikap diri dipengaruhi oleh keadaan emosional dan latar belakang serta pengalaman (experience) seseorang. Middlebrook dalam Azwar mengatakan bahwa tidak adanya pengalaman yang dimiliki oleh seseorang dengan suatu obyek psikologis, cenderung akan membentuk sikap negatif terhadap objek tersebut. Sikap akan lebih mudah terbentuk jika yang dialami seseorang terjadi dalam situasi yang melibatkan faktor emosional. Situasi yang melibatkan emosi akan menghasilkan pengalaman yang lebih mendalam dan lebih lama membekas. ${ }^{21}$

- Culture (Budaya)

Pembentukan sikap tergantung pada kebudayaan tempat individu tersebut dibesarkan. Burrhus Frederic Skinner, seperti yang dikutip Azwar sangat menekankan pengaruh lingkungan (termasuk kebudayaan) dalam membentuk pribadi seseorang. Kepribadian merupakan pola perilaku yang konsisten yang menggambarkan sejarah penguat (reinforcement) yang kita alami. Kebudayaan memberikan corak pengalaman bagi individu dalam suatu masyarakat. Kebudayaan telah menanamkan garis pengarah sikap individu terhadap berbagai masalah. ${ }^{22}$

\section{- Significant Others}

Pembentukan sikap dipengaruhi oleh orang-orang yang kita harapkan persetujuannya bagi setiap gerak tingkah laku dan opini kita, orang yang tidak ingin dikecewakan, dan yang berarti khusus. Umumnya individu tersebut akan memiliki sikap yang searah (konformis) dengan orang yang dianggap penting. Kecenderungan ini antara lain dimotivasi oleh keinginan untuk berafiliasi dan keinginan untuk menghindari konflik dengan orang yang dianggap penting tersebut.

Perbedaan posisi sikap (attitude) anak muda antara user dan non-user, juga menjelaskan hubungan antara sikap anak muda terhadap obat-obatan hingga minuman keras dengan pengalaman kedekatannya dengan teman. Hasil penelitian akhirnya menemuan bahwa terdapat empat kelompok posisi sikap (attitude), kelompok pertama bersikap anti-narkoba, dimiliki oleh para pemuda yang tidak menggunakan obat-obatan

${ }^{20}$ Narayana, Dhira dkk., Hikayat Pohon Ganja ...hlm. 61

${ }^{21}$ Azwar, Saiffudin., Sikap Manusia Teori dan Pengukurannya ... hlm. 51

${ }^{22}$ Ibid. 
terlarang dan tidak memiliki teman pengguna narkoba. Kelompok kedua bersikap ambivalen, dipegang oleh non-pengguna namun memiliki teman pengguna narkoba. Kelompok ketiga bersikap sementara, dipegang oleh pengguna ganja, dengan lingkungan pertemanan yang belum menjadi pengguna, namun berpotensi untuk masuk dalam posisi pro-obat. Sedang kelompok keempat bersikap pro-obat, dipegang oleh pengguna narkoba dan lingkungan pertemanan yang juga pengguna dengan orientasi kesenangan yang tinggi.

- Media

Media dapat berupa media cetak dan elektronik, offline, maupun online. Dalam penyampaian pesan, media akan membawa pesan-pesan sugestif yang dapat mempengaruhi opini kita. Jika pesan sugestif yang disampaikan cukup kuat, maka akan memberi dasar afektif dalam menilai sesuatu hal, hingga membentuk sikap tertentu. Berbagai bentuk media massa seperti televisi, radio, surat kabar, majalah dan lain-lain mempunyai pengaruh yang besar dalam pembentukan opini dan kepercayaan individu. Media memberikan pesan-pesan yang sugestif yang mengarahkan opini seseorang. Adanya informasi baru mengenai sesuatu hal memberikan landasan kognitif baru bagi terbentuknya sikap terhadap hal tersebut. Jika cukup kuat, pesan-pesan sugestif akan memberi dasar afektif dalam menilai sesuatu hal sehingga terbentuklah arah sikap tertentu.

- Gender

Penelitian Robin Hall menyimpulkan bahwa sikap anak-anak terhadap perang dan perdamaian dipengaruhi beberapa faktor, salah satunya gender. Penelitian ini dilakuan pada 608 siswa berusia 4-16 tahun di 10 sekolah negeri dan swasta di NSW, Australia. Anak laki-laki cenderung memiliki sikap yang lebih militeristik, sementara anak perempuan memiliki sikap lebih pacific.

Penelitian lain mengenai pengaruh jenis kelamin terhadap sikap (attitude) berjudul "The Relationship between Gender and Attitudes towards Marriage" tahun 2011 oleh Lisa Servaty dan Kirsten Weber. Penelitian ini menemukan adanya perbedaan antara sikap perempuan dan pria terhadap pernikahan. Perempuan cerderung memiliki sikap yang lebih kuat daripada laki-laki dalam hal komitmen dan menikahi orang yang dicintai.

\section{B. Hasil Penelitian}

Konsep Sikap (Attitude Merupakan sebuah konsep multidimensional yang dikonstruksikan pada diri masing-masing individu sebagai timbal balik dari suatu perilaku komunikasi. La Pierre mendefinisikan sikap (attitude) sebagai suatu pola perilaku, tendensi atau kesiapan antisipatif, predisposisi fenomena serta isu sosial politik masyarakat yang terjadi. Selain itu, pemuda khususnya mahasiswa juga merupakan kelompok mayoritas pengguna ganja. ${ }^{23}$

Karakteristik responden yang ditemukan dalam penelitan ini nyaris berimbang dari segi jenis kelamin, yakni $53 \%$ laki-laki dan $47 \%$ perempuan. Sedangkan dari segi

${ }^{23}$ Ibid., hlm. 53 
budayanya, mayoritas adalah responden adalah orang yang tidak pernah menggunakan ganja. Dari 50 responden yang diperoleh dalam penelitian ini dengan studi pada Mahasiswa Aktif fakultas keguruan dan pendidikan universitas samudra tidak pernah mengonsumsi ganja, yakni sebanya $96 \%$. Selebihnya $4 \%$ mengaku pernah mencoba-coba dalam menggunakan ganja ketika masih di pendidikan menengah atas (SMA) ganja.

Dari segi penerimaan informasi, mayoritas responden (70\%) mengaku pernah mendengar gagasan legalisasi ganja di Indonesia. Namun sebanyak 30\% responden belum pernah mendengar. Media paling banyak digunakan responden yang pernah mendengar informasi terkait gagasan legalisasi ganja adalah media baru/online media/social media. Akan tetapi, persentase terbanyak ada pada frekuensi penerimaan informasi yang jarang.

Selanjutnya adalah analisis dari variabel sikap (attitude) yang dituangkan dalam tabel dibawah berikut:

Tabel 1. Mean Indikator

\begin{tabular}{|c|c|c|c|}
\hline No & Indikator & Mean & Kategori \\
\hline 1 & Saya mengetahui UU Narkotika No. 35 Tahun 2009 & 4.90 & $\begin{array}{l}\text { Sangat } \\
\text { tinggi }\end{array}$ \\
\hline 2 & Saya mengetahui ganja menyebabkan kecanduan/ ketergantungan & 4.02 & Tinggi \\
\hline 3 & Saya mengetahui bahwa ganja termasuk dalam golongan narkotika & 4.02 & Tinggi \\
\hline 4 & $\begin{array}{l}\text { Saya mengetahui pengguna/penjual/distributor/ } \\
\text { penanam ganja akan dikenakan sanksi hukuman pidana }\end{array}$ & 4.29 & $\begin{array}{l}\text { Sangat } \\
\text { Tinggi }\end{array}$ \\
\hline 5 & Saya mengetahui adanya gagasan legalisasi ganja di Indonesia & 3.00 & Sedang \\
\hline 6 & $\begin{array}{l}\text { Saya mengetahui adanya advokasi Undang-Undang Pengelolaan } \\
\text { Ganja Republik Indonesia dan amandemen UU Narkotika No. } 35 \\
\text { Tahun } 2009\end{array}$ & 3.00 & Sedang \\
\hline 7 & $\begin{array}{l}\text { Saya mengetahui bahwa mengonsumsi ganja merupakan hak } \\
\text { pribadi masing-masing individu }\end{array}$ & 3.25 & Sedang \\
\hline 8 & $\begin{array}{l}\text { Saya mengetahui bahwa mengonsumsi ganja tidak mengganggu } \\
\text { orang Lain }\end{array}$ & 2.65 & Sedang \\
\hline
\end{tabular}

Hasil analisis yang ditemukan dalam penelitian ini adalah adanya gagasan legalisasi ganja di Indonesia. Dilihat dari mean tersebut, bahwa responden yang memiliki teman pengguna ganja memiliki sikap yang lebih postif (mendukung) dibandingkan responden yang tidak memiliki teman pengguna ganja. Namun, pada variabel diatas dalam Sikap responden menemukan tidak ada perbedaan yang signifikan antara sikap mahasiswa terhadap gagasan legalisasi ganja di Indonesia berdasarkan budaya/suku dengan nilai. 
Kemudian dalam yang dihasilkan menunjukkan adanya perbedaan yang signifikan antara sikap mahasiswa terhadap gagasan legalisasi ganja di Indonesia berdasarkan media. Responden yang medapatkan informasi mengenai legalisasi ganja di Indonesia menggunakan media sosial dan offline (tatap muka) memiliki sikap yang lebih positif/medukung dibandingkan dengan responden yang mendapatkan informasinya dari media konvensional seperti televisi, radio, majalah, atau koran

\section{Pembahasan/Analisis Terhadap Persepsi Mahasiswa Terhadap Legislasi Ganja Di Indonesia}

Konsep Sikap (attitude) dipandang sebagai kombinasi reaksi kognitif, afektif dan perilaku terhadap suatu objek. Dimensi kognitif merupakan dimensi yang terdiri dari pikiran-pikiran dan keyakinan-keyakinan seseorang terhadap objek sikap, misalnya wujud, gagasan atau konsep. Dalam penelitian ini, pengetahuan tersebut adalah mengenai gagasan legalisasi ganja di Indonesia. Gagasan tersebut meliputi advokasi UndangUndang Pengelolaan Ganja Republik Indonesia dan amandemen UU Narkotika No. 35 Tahun 2009 dengan argumen legalisasi ganja untuk pemanfaatannya dalam bidang industri, medis dan rekreasional. ${ }^{24}$

Dari hasil analisis deskriptif dapat dilihat bahwa pada dimensi kognitif, responden mayoritas memberikan penilaian yang positif. Hal ini dapat terlihat dari nilai rata-rata (mean) serta distribusi frekuensi yang dimiliki oleh masing-masing indikator dimensi kognitif. Lebih dari setengah indikator memiliki jawaban positif yang tinggi, artinya responden, yang dalam hal ini mahasiswa Fakultas keguruan dan pendidikan unsam, secara garis besar memiliki pengetahuan yang baik seputar gagasan legalisasi ganja di Indonesia. Responden yang dalam penelitian ini mahasiswa Fakultas Keguruan Dan Pendidikan Unsam juga mengetahui bahwa ganja memiliki manfaat dalam segi medis dan industri. Akan tetapi pengetahuan responden akan hak-hak individu terhadap ganja sedikit berbeda. Mereka mengetahui bahwa mengonsumsi ganja merupakan hak masing-masing individu walaupun mengonsumsinya tetap saja dapat mengganggu orang lain.

Selanjutnya berkaitan dengan perasaan yang menyangkut reaksi emosi seseorang terhadap gagasan legalisasi ganja di Indonesia. Gagasan tersebut meliputi advokasi Undang-Undang Pengelolaan Ganja Republik Indonesia dan amandemen UU Narkotika No. 35 Tahun 2009 dengan argumen legalisasi ganja untuk pemanfaatannya dalam bidang industri, medis dan rekreasional.

Dari hasil analisis deskriptif dapat dilihat bahwa, responden mayoritas memberikan penilaian yang netral. Hal ini dapat terlihat dari nilai rata-rata (mean) serta distribusi frekuensi yang dimiliki oleh masing-masing indikator dimensi afektif. Artinya responden yang dalam hal ini mahasiswa Fakultas Keguruan Dan Pendidikan Unsam memiliki reaksi emosi yang tidak secara ekstrim berpihak untuk menyukai ataupun tidak menyukai gagasan legalisasi ganja di Indonesia, melainkan memilih untuk netral. Posisi netral tersebut terjadi karena terdapat ketertarikan yang berbada pada masing-masing poin gagasan legalisasi ganja di Indonesia. Mayoritas responden mengatakan menyukai poin bahwa ganja memiliki manfaat dalam segi industri dan medis. Akan tetapi mereka juga

${ }^{24}$ Ibid. 
tetap menyukai pernyataan bahwa ganja dapat menyebabkan kecanduan dan dapat mengganggu orang lain. Hal ini memperkuat posisi ketidaksukaan responden terhadap poin gagasan legalisasi ganja dalam hal rekreasional karena cukup banyak yang menganggap ganja merupakan bagian dari narkotika dan menyukai peratuan sanksi hukuman pidana bagi pengguna/penjual/distributor/penanam ganja di Indonesia meskipun mayoritas dari mereka menyukai pernyataan bahwa mengonsumsi ganja merupakan hak masing-masing individu.

Dimensi yang terdiri dari tindakan atau kecenderungan orang untuk berperilaku yang nampak terhadap obyek sikap (attitude). Dalam dimensi ini akan berkaitan dengan perilaku mahasiswa terhadap gagasan legalisasi ganja di Indonesia. Gagasan tersebut meliputi advokasi Undang-Undang Pengelolaan Ganja Republik Indonesia dan amandemen UU Narkotika No. 35 Tahun 2009 dengan argumen legalisasi ganja untuk pemanfaatannya dalam bidang industri, medis dan rekreasional.

Dari hasil analisis deskriptif dapat dilihat bahwa mayoritas responden memberikan penilaian yang positif. Hal ini dapat terlihat dari nilai rata-rata (mean) serta distribusi frekuensi yang dimiliki oleh masing-masing indikator pada dimensi konatif. Dari delapan indikator, 6 indikator memiliki jawaban positif yang tinggi. Akan tetapi, apabila dilihat dari rata-rata (mean) keseluruhan yang sebesar 3.00 artinya responden yang dalam hal ini mahasiswa Fakultas Keguruan Dan Pendidikan Unsam secara garis besar berada pada tingkatan sedang untuk mendukung gagasan legalisasi ganja di Indonesia.

Analisis lebih detil untuk menjelaskan posisi netral pada dimensi konatif ini akan dijabarkan lebih lanjut. Mayoritas mahasiswa mendukung bahwa ganja masuk dalam golongan narkotika dan mereka juga mendukung peraturan sanksi hukuman pidana bagi pengguna/penjual/distibutor/penanam ganja di Indonesia karena mengonsumsi ganja dinilai akan mengganggu orang lain dan menyebabkan kecanduan, meskipun sebanyak sebagian responden secara mayoritas mendukung pernyataan bahwa mengonsumsi ganja merupakan hak masing-masing individu.

Akan tetapi, peneliti juga menemukan mahwa mayoritas responden juga ternyata tidak mendukung sepenuhnya pelaksanaan UU Narkotika No. 35 Tahun 2009 di Indonesia saat ini. Wawancara lebih lanjut yang dilakukan oleh 10 responden mengatakan bahwa alasan mereka tidak mendukung pelaksanaan undang-undang tersebut meskipun mereka mendukung sanksi pidana untuk pengguna/penjual/distributor/penanam ganja adalah terdapat pada poin keputusan hukum yang diberikan. Mereka mengatakan setuju dengan komponen isi peraturan perundang-undangan beserta ketentuan sanksinya, akan tetapi pelaksanaan realitanya dilapangan kerap tidak sesuai dengan peraturan yang sebenarnya. Ada beberapa keputusan yang dirasa kurang adil, namun ada pula yang dirasa terlalu ringan. Maka dari itu perlu ditinjau kembali pelaksanaan dan evaluasi mengenai perundang-undangan tersebut. Selanjutnya mayoritas responden ternyata mendukung adanya legalisasi ganja di Indonesia secara umum terutama pada pemanfaat ganja dalam industri dan medis.

Secara keseluruhan, rata-rata (mean) variabel sikap (attitude) adalah 3,00. Angka ini termasuk dalam kategori netral. Responden secara general tidak terlihat setuju ataupun tidak setuju dalam keseluruhan gagasan legalisasi ganja di Indonesia. Sejalan dengan sikap mahasiswa yang juga netral dengan nilai 3.00 atas amandemen UU Narkotika No. 
35 Tahun 2009 di Indonesia dan advokasi Undang Undang Pengelolaan Ganja Republik Indonesia Akan tetapi apabila dianalisis lebih detil dan terpisah, responden ditemukan setuju dengan poin legalisasi ganja dalam pemanfaatannya untuk bidang industri dan medis. Hal ini dapat dilihat dari nilai mean yang sangat tinggi pada indikator pemanfaatan ganja dalam bidang industri dan bidang medis tersebut. Hal yang membuatkan sikap mahasiswa menjadi netral secara keseluruhan adalah karena sangat rendahnya nilai mean pada gagasan legalisasi ganja untuk rekresional.

Jika dilihat dari persentase pada seluruh indikator yang ada, sikap yang tidak setuju akan gagasan legalisasi ganja di Indonesia untuk rekreasional bisa dikarenakan pengetahuan yang sangat sedikit mengenai UU Narkotika No.35 Tahun 2009 sendiri dan anggapan yang masih mendominasi bahwa ganja menyebabkan ketergantungan dan bisa mengganggu orang lain. Sedangkan sikap setuju yang tinggi terhadap gagasan legalisasi ganja di Indonesia dalam bidang industri dan medis bisa pula dikarenakan pengetahuan yang sudah sangat baik terhadap informasi tersebut.

Sikap tersebut ternyata juga dipengaruhi oleh empat faktor, yakni self experience, significant others, media, dan gender. Pertama pengalaman pribadi (self experience). Hasil penelitian menunjukkan bahwa terdapat perbedaan yang signifikan antara sikap responden pengguna ganja (user) dengan sikap responden bukan pengguna ganja (nonuser) terhadap gagasan legalisasi ganja di Indonesia. Responden yang pernah menggunakan ganja memiliki sikap lebih positif atau setuju dengan gagasan legalisasi ganja di Indonesia. Meskipun presentase responden yang pernah menggunakan ganja jauh sangat sedikit dibandingan bukan pengguna, namun perbedaan yang dihasilkan tetap signifikan.Penemuan ini telah membuktikan pernyataan dari konsep utilitarium function dan the ego defensife function yang dikemukakan oleh Katz sebagai fungsi dari sikap. ${ }^{25}$

Utilitarium function mengatakan bahwa seseorang meyetujui atau menyukai suatu gagasan dikarenakan fungsi atau manfaat yang akan didapat pada dirinya. Responden pengguna ganja akan cenderung menyetujui gagasan legalisasi ganja ini karena mereka merasakan manfaatnya apabila terealisasikan. Manfaat dalam hal ini adalah mengonsumsi ganja itu sendiri dengan bebas tanpa tebatasi oleh ancaman hukuman pidana seperti yang berlaku hingga saat ini. Sedangkan the ego defensife function merupakan konsep yang menjelaskan bahwa keberadaan sikap akan melindungi seseorang dari ancaman eksternal maupun perasaan dari dalam dirinya. Hal ini berlaku untuk kedua responden. Responden yang pernah menggunakan ganja membentuk sikap postif tegas dikarenakan untuk melindungi dirinya dari ketidaktenangan yang dirasakan selama ganja masih dilarang di Indonesia. Dan bagi responden bukan pengguna ganja, sikap yang tidak mendukung merupakan bukti dari upaya mereka dalam melindungi citra diri dari keraguan, bahwa mereka memiliki pendirian.

Faktor kedua yang mempengaruhi sikap adalah significant others atau lingkungan pertemanan yang berpengaruh. Dari penelitian ini, dapat disimpulkan bahwa responden yang memiliki teman pengguna ganja memiliki sikap lebih positif atau mendukung gagasan legalisasi ganja di Indonesia dibandingkan responden yang tidak memiliki teman

${ }^{25}$ Wawan. A dan M. Dewi. Teori dan Pengukuran Pengetahuan, Sikap, Dan Perilaku Manusia .... Loc., Cit. 
pengguna ganja. Jalaluddin Rakhmat dalam bukunya "Psikologi Komunikasi" mengatakan bahwa sikap timbul dari pengalaman, tidak dibawa sejak lahir melainkan hasil dari pembelajaran. Karena itu sikap dapat dibentuk atau diubah, tergantung dari lingkungan pembelajaran seseorang. Bisa saja sikap awal seorang yang kontra terhadap legalisasi ganja pada awalnya, berubah menjadi sangat pro ketika ia telah sering bergaul di lingkungan pertemanan pengguna ganja. ${ }^{26}$

Faktor ketiga yang berpengaruh dalam pembentukan sikap seseorang adalah media. Ditemukan bahwa responden yang mengaku menerima informasi mengenai gagasan legalisasi ganja di Indonesia melalui social media memiliki sikap yang jauh lebih positif terhadap gagasan tersebut dibandingkan dengan responden yang menerimanya melalui media konvensional seperti televisi, radio, majalah, dan koran.

Namun penemuan yang menarik juga didapatkan melalui penelitian ini terkait media. Ternyata responden yang juga memiliki sikap sangat positif atau mendukung legalisasi ganja di Indonesia ini mengaku menerima informasinya melalui media offline, yakni tatap muka dalam acara kampanye atau special event. Walaupun frekuensi penerimaan informasinya terbilang jauh lebih sedikit dibandingkan media sosial dan konvensional, tetapi sikap yang dibentuk tetap bisa positif. Ini dikarenakan bahwa orangorang yang biasanya hadir dalam acara offline gerakan legalisasi ganja di Indonesia ini merupakan simpatisan atau anggota organisasi Lingkar Ganja itu sendiri. Dengan kata lain, mereka memang telah memiliki latar belakang pendukung gagasan legalisasi ganja ini.

Faktor terakhir atau keempat yang mempengaruhi sikap seseorang adalah gender. Hasil dari penelitian ini membuktikan bahwa responden laki-laki cenderung lebih positif atau mendukung gagasan legalisasi ganja di Indonesia dibandingkat perempuan yang cenderung netral. Ini dikarenakan pengguna narkotika (termasuk ganja) di Indonesia sebagian besar adalah pemuda berumur 20-25 tahun yang 90\% nya adalah pria. Survey ini dilakukan oleh Perhimpunan Ahli Penyakit Dalam Indonesia (PAPDI) cabang DKI Jaya. Dengan demikian maka hasil ini dapat dikaitkan pula dengan self experience responden sehingga membuat ia memutuskan untuk mendukung.

Dari keempat faktor yang diteliti, ternyata hanya tiga yang memiliki pengaruh signifikan terhadap sikap seseorang terhadap gagasan legalisasi ganja di Indonesia. Variabel yang tidak terbukti memiliki pengaruh adalah budaya. Ini menunjukkan bahwa budaya tidak selamanya berpengaruh terhadap pembentukan sikap seseorang. Namun hal ini tidak berlaku dalam konteks legalisasi ganja. Bisa juga dikarenakan sebagian besar responden merupakan mahasiswa dari luar daerah yang mengikuti perkuliahan. Sehingga kebanyakan budaya tradisional atau asli yang mereka miliki tidak terlalu berpengaruh.

Dari kesimpulan diatas dapat disimpulkan bahwa persepsi mahasiswa terhadap legislasi ganja di indonesia masih banyak memiliki pandangan yang berbeda dimana sebagian mahasiswa mendukung adanya legislasi ganja dan sebagian mahasiswa yang lain lebih bersikap tidak mendukung dan bersifat netral.

\footnotetext{
${ }^{26}$ Rakmat, Jalaluddin. Psikologi Komunikasi. (Bandung: Remaja Rosdakarya., 2004). hlm. 22
} 


\section{Penutup}

Adapun kesimpulan yang dapat ditarik dari penelitian ini menyimpulkan bahwa responden yang dalam hal ini mahasiswa Fakultas Keguruan dan Pendidikan Unsam, memiliki sikap netral terhadap gagasan legalisasi ganja di Indonesia. Netral tersebut terjadi karena adanya perbedaan sikap responden pada masing-masing poin legalisasi ganja. Responden cenderung tidak setuju apabila ganja dilegalkan untuk rekreasional, namun sangat setuju apabila ganja menjadi legal pemanfaatannya dalam bidang industri dan medis. Sikap ini dipengaruhi oleh empat faktor, yakni gender, media, pengalaman pribadi (self experience), dan lingkungan pertemanan (significant others).

Sementara itu, saran yang dapat direkomendasikan adalah agar dilakukan penelitian lanjutan mengenai sikap (attitude) masyarakat terhadap gagasan legalisasi ganja di Indonesia, secara kuantitatif dengan melihat hubungannya dengan kampanye atau komunikasi persuasif dengan penarikan sampel yang probabilita, sehingga generalisasinya lebih kuat. Selain itu penelitian lanjutan secara kualitatif juga diperlukan dengan wawancara mendalam sehingga bisa menggali informasi apa saja, dan bagaimana faktor-faktor yang mempengaruhi sikap tersebut dapat mempengaruhi seseorang. Dengan wawancara mendalam juga bisa ditemukan faktor-faktor lain yang mempengaruhi sikap dengan analisis yang lebih mendalam pula.

Sedangkan, saran dalam tataran praktis ditujukan kepada para pihak yang berupaya untuk menyebarkan gagasan legalisasi ganja di Indonesia bahkan hingga sampai tahapan persuasif untuk mengadvokasi amandemen UU Narkotika No.35 Tahun 2009 atau pembuatan Undang-Undang Pengelolaan Ganja Republik Indonesia agar lebih menganalisa lagi poin-poin legalisasi ganja yang akan diajukan. Melihat posisi ganja yang kontroversial namun telah ditetapkan dalam tempo yang cukup lama terdahulu sebagai tanaman yang termasuk dalam golongan narkotika golongan 1 serta dapat menganggu serta membahayakan orang lain dan penggunanya. Hal ini untuk menghindari upaya legalisasi ganja yang oportunis, dengan kata lain untuk menguntungkan pengguna rekreasionalnya saja agar tidak mendapatkan hukuman pidana bila mengonsumsi/menjual/mendistribusi/ menanam ganja tersebut.

Hal ini telah dibuktikan dari penelitian ini dengan ketidaksetujuan resposden khususnya mahasiswa terhadap pemanfaatan ganja untuk rekreasional. Namun mahasiswa setuju gagasan legalisasi ganja dalam bidang industri dan media tentunya dengan sistem dan pengelolaan yang baik dan benar.

\section{Daftar Pustaka}

\section{Buku:}

Azwar, Saiffudin., Sikap Manusia Teori dan Pengukurannya., Yogyakarta: Pustaka Pelajar, 2003

Hart, Carl L. At all., Drugs, Society and Human Behavior. New York: McGraw-Hill., 2009. 
Narayana, Dhira dkk., Hikayat Pohon Ganja., Jakarta: PT Gramedia Pustaka Utama, 2011

Oskamp, Stuart dan Schultz, P. Wesley., Attitudes and Opinions., London: Lawrence Erlbaum, 2005

Patton, George C dkk. Cannabis Use and Mental Health in Young People, Cohort Study, 2002.

Rakmat, Jalaluddin., Psikologi Komunikasi. Bandung: Remaja Rosdakarya, 2004

I

Wawan. A dan M. Dewi., Teori dan Pengukuran Pengetahuan, Sikap, Dan Perilaku Manusia Dilengkapi contoh Kuesioner. Cetakan Pertama. Yogyakarta: Nuha Medika., 2010.

Zulganef. Metode Penelitian Sosial \& Bisnis. Yogyakarta: Graha Ilmu., 2008

\section{Internet:}

Gobel, Fatmah Afrianty, Ganja Aceh Untuk Medis, Halalkah?., http://www.atjehcyber.net/2011/11/ganja-aceh-demi-dunia-medis.html, diakses pada tanggal 23 Oktober 2017.

Sharley, Delvi., Budaya Ganja di Aceh., http://www.legalisasiganja.com/budaya-ganjadi-aceh/, diakses pada tanggal 24 oktober 2017

Tobing, Letezia, Hukum Menanam Cannabis (Ganja), http://www.hukumonline.com/klinik/detail/lt522150607489f/hukum-menanamcannabis-(ganja), diakses pada pada tanggal 19 Oktober 2017.

Wicaksana, Inu, Jaman Dulu 'Gelek', Sekarang 'Cimeng', Itulah Ganja Pengganti HeroinI, http://kesehatan.kompasiana.com/kejiwaan/ 2011/05/27/jaman-dulugelek-sekarang-cimeng-itulah-ganja-pengganti-heroin-368354.html, diakses pada tanggal 24 oktober 2017. 